\title{
Flavonoids from the Leaves of Deguelia utilis (Leguminosae): Structural Elucidation and Neuroprotective Properties
}

\author{
Dalglish G. de Oliveira, ${ }^{a}$ Cecília M. C. de Almeida, ${ }^{a}$ Consuelo Y. Y. e Silva,${ }^{a}$ Mara S. P. Arruda, ${ }^{a}$ \\ Alberto C. Arruda, ${ }^{a}$ Dielly C. F. Lopes, ${ }^{b}$ Elizabeth S. Yamada, ${ }^{b}$ Edmar T. da Costa ${ }^{b}$ and Milton N. da Silva*,a \\ ${ }^{a}$ Laboratório de Cromatografia Líquida, Universidade Federal do Pará, \\ Rua Augusto Corrêa, 01, Guamá, 66075-110 Belém-PA, Brazil \\ ${ }^{b}$ Laboratório de Neuropatologia Experimental, Hospital Universitário Barros Barreto, \\ Rua dos Mundurucus, 4487, Guamá, 66073-000 Belém-PA, Brazil
}

\begin{abstract}
Das folhas de Deguelia utilis foram isolados cinco flavonoides: 5,3'-di-hidróxi-4'-metóxi-2",2"dimetilcromeno-(5",6":6,7)-di-hidroflavonol (1), 5,3'-di-hidróxi-7,4'-dimetóxi-6,8-dimetilalildi-hidroflavonol (2), 5,3'-di-hidróxi-4'-metóxi-8-prenil-2",2"'-dimetilcromeno-(5",6":6,7)flavanona (3), 5,3'-di-hidróxi-7,4'-dimetóxi-6,8-dimetilalil-flavanona (4), 3,5,3'-tri-hidróxi-7,4'dimetóxi-6,8-dimetilalil-flavanol (5), juntamente com os estilbenos: 4-metoxilonchocarpeno (6) e lonchocarpeno (7). Suas estruturas químicas foram elucidadas com base nos seus dados de NMR (ressonância magnética nuclear) e HRESITOF-MS (espectrometria de massas de alta resolução por tempo de vôo, com ionização por eletrospray). Além disso, a fim de investigar o potencial efeito citoprotetor desses flavonoides, foi utilizada uma fração eluída com hexano:AcOEt contendo os sete flavonoides, em um modelo in vitro de neurodegeneração, utilizando culturas primárias do hipocampo de ratos neonatal (PND2-P3) expostos à rotenona, um inibidor mitocondrial do complexo I. Houve uma redução significativa da viabilidade celular $(19,4 \pm 1,6 \%)$, quando as culturas foram expostas à rotenona $30 \mathrm{nmol} \mathrm{L}^{-1}$ por $72 \mathrm{~h}$. A exposição concomitante das culturas a FR3 $\left(5 \mu \mathrm{g} \mathrm{mL} \mathrm{m}^{-1}\right)$ e rotenona $30 \mathrm{nmol} \mathrm{L}^{-1}$ resultou em valores de viabilidade celular semelhante ao grupo controle $(99,6 \pm 4,8 \%)$, sugerindo um efeito citoprotetor para essa fração.
\end{abstract}

Five new flavonoids, 5,3'-dihydroxy-4'-methoxy-2",2"'-dimethylchromene-(5",6":6,7)dihydroflavonol (1), 5,3'-dihydroxy-7,4'-dimethoxy-6,8-dimethylallyl-dihydroflavonol (2), 5,3'-dihydroxy-4'-methoxy-8-allyl-2", 2"'-dimethylchromene-(5", 6":6,7) flavanone (3), 5,3'-dihydroxy-7,4'-dimethoxy-6,8-dimethylallyl-flavanone (4), 3,5,3'-trihydroxy-7,4'-dimethoxy6,8-dimethylallyl-flavanol (5), together with the stilbenes 4-methoxylonchocarpene (6) and lonchocarpene (7) were isolated from the leaves of Deguelia utilis. Their chemical structures were established on the basis of NMR (nuclear magnetic resonance) spectral data and HRESITOF-MS (electrospray ionization-high resolution time-of-flight mass spectrometry). Also, in order to investigate potential cytoprotective effects of these flavonoids, we used a fraction eluted with hexane:EtOAc containing all seven flavonoids, in an in vitro model of neurodegeneration, using hippocampal primary cultures from neonatal (PND2-P3) rats exposed to rotenone, a mitochondrial complex I inhibitor. There was a significant reduction in cell viability $(19.4 \pm 1.6 \%)$ when the cultures were exposed to $30 \mathrm{nmol} \mathrm{L}^{-1}$ rotenone for $72 \mathrm{~h}$. Concomitant exposure of the cultures to the FR3 $\left(5 \mu \mathrm{g} \mathrm{mL}^{-1}\right)$ and $30 \mathrm{nmol} \mathrm{L}^{-1}$ rotenone resulted in values of cell viability similar to control groups $(99.6 \pm 4.8 \%)$, strongly suggesting a cytoprotective effect for this flavonoid-rich fraction.

Keywords: Deguelia utilis, flavonoids, leguminosae, timbó

\section{Introduction}

Brain energy metabolism is highly dependent on mitochondria oxidative phosphorylation, which is an

*e-mail: yumilton@yahoo.com.br important source of free radicals. When free radical production exceeds the availability of endogenous and exogenous antioxidants, oxidative stress prevails, leading to cell damage. Not surprisingly, oxidative damage has been implicated in the pathogenesis of a number of neurodegenerative diseases such as Alzheimer's disease, 
Parkinson's disease, amyotrophic lateral sclerosis, Huntington's disease, as well as others. ${ }^{1}$ Thus, strategies aimed at fighting the excess of free radicals may be beneficial for slowing down or arresting the degeneration process and natural products are an attractive source of antioxidant compounds with promising pharmacological properties. Therefore, natural products continue to play a fundamental role in the discovery of leads for developing new drugs for treating human diseases. ${ }^{2}$

The genus Deguelia belonging to the family Leguminosae comprises 20 species, among which $D$. rufescens var. urucu and $D$. utilis are considered the most used by indigenous population of the Amazon region for catching fish. D. utilis is a shrub with wide distribution in the Amazon basin, and it is commonly known in the region as "timbó branco". This shrub can reach 3 meters of height and its roots are well known for their piscicide and pesticide properties attributed to its high contents of rotenoids such as rotenone and deguelin. ${ }^{3-5}$ Rotenone, which can be extracted from Deguelia roots, is a lipophilic mitochondrial complex I inhibitor, and it has been widely used as a neurotoxicant in both in vivo and in vitro models of Parkinson's disease. ${ }^{6}$

Regarding studies about Deguelia spp., many phytochemical reports are found in the literature describing the chemistry of the roots. ${ }^{7-12}$ To date, however, there are only a few publications about the phytochemical properties of the leaves of these species, and they have reported the presence of several flavonoid compounds with potential antioxidant properties. ${ }^{13,14}$

In this study we sought to perform a phytochemical characterization of the leaves from $D$. utilis and investigated the presence of compounds with potential neuroprotective properties. A flavonoid-rich fraction extracted from $D$. utilis leaves (FR3) was tested for its potential neuroprotective properties in a cell culture model of neurodegeneration induced by rotenone. Our results showed that the use of a very small concentration of the fraction was able to abolish rotenone-induced cell loss, as determined by the MTT colorimetric assay.

\section{Experimental}

\section{General}

UV spectra were obtained from LC equipped with DAD Prominence SPDM-20A (Shimadzu, Tokio, Japan). NMR spectra including ${ }^{1} \mathrm{H}-{ }^{1} \mathrm{H}$ COSY, HETCOR, HMBC experiments, were recorded on a Varian Mercury-300 spectrometer, operating at $300 \mathrm{MHz}$ at ${ }^{1} \mathrm{H}$ and $75 \mathrm{MHz}$ at ${ }^{13} \mathrm{C}$, using $d$-chloroform as solvent and internal standard. Mass spectral analyses were performed on UltrOTOF-Q
(Bruker, Daltonics Billerica MA, USA) at the cationized ion region. The heated capillary and voltage were maintained at $250{ }^{\circ} \mathrm{C}$ and $3 \mathrm{kV}$, respectively. A $20 \mathrm{~V}$ cone energy for ion extraction and mass spectrometry data were acquired at positive and negative modes for all compounds. HPLC was carried out in a preparative LC-8A Shimadzu system with SPD-10AV Shimadzu UV detector (Tokyo, Japan); using a Phenomenex Gemini C18 column $(250 \times 10 \mathrm{~mm}, 5 \mu \mathrm{m})$, an isocratic system of water/acetonitrile (3:7) and a flow rate of $4.7 \mathrm{~mL} \mathrm{~min}^{-1}$. Detection was performed at 270 and $325 \mathrm{~nm}$. All solvents were filtered through a $0.45 \mu$ m nylon membrane filter prior to analysis.

\section{Plant material}

Approximately $1.3 \mathrm{Kg}$ of green leaves of D. utilis (A. C. Sm.) A. M. G. Azevedo (sinonimia: Lonchocarpus nicou and Derris nicou) were collected in the forest reserve of EMBRAPA -Amazônia Oriental, located in Belém, Pará at $01^{\circ} \mathrm{S} 48^{\circ} \mathrm{W}, 10 \mathrm{~m}$. The plant was identified and a Voucher (Exsiccate IAN 181063) was deposited in the EMBRAPA Herbarium.

\section{Extraction and isolation}

An amount of $480 \mathrm{~g}$ of dried and powdered D. utilis leaves was extracted with $3 \mathrm{~L}$ of ethanol at room temperature for $24 \mathrm{~h}$ (two times). The solvent was removed under reduced pressure, furnishing $80 \mathrm{~g}$ of crude ethanolic residue, from which $50 \mathrm{~g}$ were fractionated in a silica gel (40-60 $\mu \mathrm{m}, 1: 10)$ column chromatography with gradient elution: hexane-EtOAc 9:1 (FR1 1.85 g), 7:3 (FR2 $2.50 \mathrm{~g}$ ), 5:5 (FR3 $11.63 \mathrm{~g}$, AcOEt (FR4 2.75 g) and EtOAc-MeOH 7:3 (FR5 $1.22 \mathrm{~g}$ ) and $\mathrm{MeOH}$ (FR6 $8.70 \mathrm{~g}$ ). Fraction FR3 $(0.4 \mathrm{~g})$, was sonicated in $4.8 \mathrm{~mL}$ of acetonitrile for $1 \mathrm{~min}$. Next $1.2 \mathrm{~mL}$ of $\mathrm{H}_{2} \mathrm{O}$ was added and sonicated again for $1 \mathrm{~min}$. Solution was subjected to solid phase extraction (SPE) in a C18 cartridge (Phenomenex, $1 \mathrm{~g}$ of stationary phase per $6 \mathrm{~mL}$ ). After evaporation, the residue (about $260 \mathrm{mg}$ ) was purified by semi-preparative HPLC yielding compounds 1 (23.0 mg), 2 (42.4 mg), 3 (13.0 mg), $4(16.2 \mathrm{mg}), \mathbf{5}(11.4 \mathrm{mg}), \mathbf{6}(21.7 \mathrm{mg})$ and $\mathbf{7}(10.5 \mathrm{mg})$, which showed chromatographic peak retention times of $11.3,20.9,25.0,31.8,37.2,16.6$ and $9.4 \mathrm{~min}$, respectively.

\section{Cell culture and rotenone exposure}

Mixed primary hippocampal cultures were prepared from postnatal day 2 (PND2) - PND3 Wistar rats. Pups were sacrificed by decapitation; the brain was rapidly removed and dissected in a petri dish with sterile dissection medium. The hippocampus was isolated free of meninges 
and incubated for $5-10 \mathrm{~min}$ at $37{ }^{\circ} \mathrm{C}$ in a trypsin-EDTA $0.05 \%$ solution (Invitrogen) for enzymatic digestion, and then transferred to culture medium DMEM containing $10 \%$ fetal bovine serum (FBS), $10 \%$ horse serum (HS) and penicillin-streptomycin $10,000 \mathrm{U} \mathrm{mL}^{-1}$. After that, the tissue was mechanically dissociated with a sterile fire-polished Pasteur pipette. The cells contained in the supernatant were then plated at a density of approximately $5 \times 10^{5}$ cells per well in plates previously treated with poly-L-lysine $\left(100 \mu \mathrm{g} \mathrm{mL}^{-1}\right)$ containing DMEM supplemented with $10 \%$ FBS, $10 \%$ HS and penicillin-streptomycin. The cultures plates were kept in $5 \% \mathrm{CO}_{2} / 95 \% \mathrm{O}_{2}$ at $37{ }^{\circ} \mathrm{C}$. After three days, the cultures were replenished with new medium. Until vehicle or rotenone exposure, the cultures were maintained in DMEM supplemented with $2 \% \mathrm{FBS}, 2 \% \mathrm{HS}$, and penicillin-streptomycin. ${ }^{15,16}$

After 7 days in vitro (DIV), the cells were pretreated with increasing concentrations of FR3 $\left(3 \mu \mathrm{g} \mathrm{mL}^{-1}, 5 \mu \mathrm{g} \mathrm{mL} \mathrm{m}^{-1}\right.$ and $\left.10 \mu \mathrm{g} \mathrm{mL}^{-1}\right)$ in order to evaluate its toxicity or FR3 plus $30 \mathrm{nmol} \mathrm{L}^{-1}$ rotenone for $72 \mathrm{~h}$. Rotenone was prepared from a stock solution of $1 \mathrm{mmol} \mathrm{L}^{-1}$ in $0.1 \%$ of dimethyl sulfoxide (DMSO) and then diluted in DMEM to the final concentration. These concentrations of rotenone were chosen, since similar concentrations have been reported in studies of neuron degeneration and/or oxidative stress. ${ }^{17-19}$

\section{Immunocytochemistry}

In order to assure that our protocol resulted in a mixture of neurons and glial cells in the primary cultures, cells were plated in wells containing a coverslip of $13 \mathrm{~mm}$ in diameter covered with poly-L-lysine. Antibody against the enzyme tyrosine hydroxylase (Millipore, 1:1000) to characterize catecholaminergic (dopaminergic) neurons was used. Microglia cells were stained with OX-42 antibody (Sigma 1:1000) which recognizes the complement receptor type 3 (CR3), and astrocytes were labeled with anti-GFAP antibody (Sigma 1:2000). After 7 DIV, plates were washed with PBS and fixed with $3.7 \%$ formaldehyde in PBS for $30 \mathrm{~min}$ at room temperature. The cultures were then washed again and incubated overnight at $4{ }^{\circ} \mathrm{C}$ with primary antibody. Next, cells were washed and then incubated for $2 \mathrm{~h}$ with a donkey biotinylated secondary antibody (Jackson Immuno Research, 1:200). After washing, cultures were incubated for $1 \mathrm{~h}$ with Vectastain $\mathrm{ABC}$ reagents diluted according to manufacturer's instructions. The visualization of the complex formed was done by incubation of cultures with hydrogen peroxide and DAB (3,3'-diaminobenzidine) in PBS. Slides were coverslipped with mounting medium (Permount), and were analyzed and photographed under a Nikon Labophot 2 microscope (Nikon Microscopy Systems).

\section{Cell viability assay}

Cell viability was checked using the MTT ((3-(4,5-dimethylthiazol-2-yl)-2,5-diphenyltetrazolium bromide) method. MTT is a salt that is reduced by the mitochondrial dehydrogenase of viable cells and is detected by this assay. Cultures were exposed to $1 \mu \mathrm{g} \mathrm{mL} \mathrm{m}^{-1} \mathrm{FR} 3$ or FR3 plus $30 \mathrm{nmol} \mathrm{L} \mathrm{L}^{-1}$ rotenone, during 3 days, at $37{ }^{\circ} \mathrm{C}$ and $5 \% \mathrm{CO}_{2}$. The cells were then washed and incubated with PBS plus $50 \mu \mathrm{L}$ of MTT for $3-4 \mathrm{~h}$ at $37{ }^{\circ} \mathrm{C}$ and $5 \%$ $\mathrm{CO}_{2}$. Subsequently, cells were scraped off, transferred to glass tubes, and the absorbance at $570 \mathrm{~nm}$ was measured in a spectrophotometer.

\section{Statistics}

Data were expressed as mean \pm standard error of mean (SEM). Statistical significance was calculated using the ANOVA associated with Tukey's test. For comparison of control and rotenone values, the Mann-Whitney $U$ test was used. Differences within the groups of $\mathrm{P}<0.05$ were regarded as statistically significant.

\section{Results and Discussion}

\section{Phytochemical investigation}

The dried and powdered leaves of D. utilis were extracted with $\mathrm{EtOH}$. The ethanolic extract was fractionated by silica gel column chromatography, which provided six fractions. Chromatographic separation of the hexane:EtOAc $50 \%$ soluble fraction by semi-preparative HPLC led to the isolation of pure compounds 1-7 (Figure 1). Compounds 6 and 7 were identified as 4-methoxylonchocarpene and lonchocarpene, respectively, by comparison of their spectral data with those reported in literature. ${ }^{20,21}$

Compoud 1 was obtained as a pale yellow powder. The molecular formula $\mathrm{C}_{26} \mathrm{H}_{28} \mathrm{O}_{7}$ was determined by HRESITOF-MS at $\mathrm{m} / z$ 453.1909 $[\mathrm{M}+\mathrm{H}]^{+}$(calc. for $\mathrm{C}_{26} \mathrm{H}_{29} \mathrm{O}_{7}, 453.1913$ ). Its ${ }^{1} \mathrm{H}$ NMR spectrum (Table 1) exhibited a typical AX system due to $\mathrm{H}-2$ and $\mathrm{H}-3$ of a dihydroflavonol at $\delta_{\mathrm{H}} 4.95(d, J 11.7 \mathrm{~Hz})$ and $4.47(d$, $J 11.7 \mathrm{~Hz}$ ), respectively. These assignments were confirmed by the ${ }^{13} \mathrm{C}$ NMR spectrum (Table 2), which showed three C-ring carbon signals at $\delta_{\mathrm{C}} 82.8(\mathrm{C}-2), 72.4(\mathrm{C}-3)$ and 196.2 (C-4). The configuration at C-2/C-3 was determined to be trans on the basis of the magnitude of $J_{\mathrm{H} 2-\mathrm{H} 3} 11.7 \mathrm{~Hz}$. Additionally, the ${ }^{1} \mathrm{H}$ NMR spectrum exhibited signals in the aromatic region at $\delta_{\mathrm{H}} 7.14(d, 1 \mathrm{H}, J 1.6 \mathrm{~Hz}), 7.02(d d, 1 \mathrm{H}$, $J 8.1,1.6 \mathrm{~Hz})$ and $6.89(d, 1 \mathrm{H}, J 8.1 \mathrm{~Hz})$, which indicated an AMX spin system of a 1,3,4-trisubstituted phenyl group. 
<smiles>[R]C1C(=O)c2c(O)c3c(c([CH]C=C(F)F)c2OC1c1ccc(OC)c(O)c1)OC(C)(C)C=C3</smiles>

1: $\mathrm{R}=3 \beta \mathrm{OH}$

3: $\mathrm{R}=\mathrm{H}$<smiles>[R]C1C(=O)c2c(O)c(CC=C(C)F)c(OC)c([CH]C=C(C)F)c2OC1c1ccc(OC)c(O)c1</smiles><smiles>[R]c1c(OC)cc(/C=C/c2ccc3c(c2)C=CC(C)(C)O3)cc1OC</smiles>

7: $\mathrm{R}=\mathrm{H}$

Figure 1. Structures of the compounds isolated from leaves of Deguelia utilis: prenyl-urucuol A (1), prenyl-isotirumalin (2), 3'-methoxylupinifolin (3), prenylutiline (4), prenylutilinol (5), 4-methoxylonchocarpene (6) and lonchocarpene (7).

The signals observed at $\delta_{\mathrm{H}} 6.63$ and $5.52(d, 1 \mathrm{H}$ each, $J 9.9 \mathrm{~Hz})$ and $1.44(6 \mathrm{H}, s)$ revealed a 2,2-dimethylchromene ring attached to an aromatic ring, and the singlet at $\delta_{\mathrm{H}}$ 11.42 indicated the presence of a hydroxyl group bonded to $\mathrm{C}-5$ and one OMe group at $\delta_{\mathrm{H}} 3.91\left(\delta_{\mathrm{C}} 55.9\right)$ bonded to the aromatic ring.

All the couplings were confirmed through analysis of the ${ }^{1} \mathrm{H}-{ }^{1} \mathrm{H}$ COSY spectrum. In addition to the signals related to C-ring carbons, the ${ }^{13} \mathrm{C}$ NMR spectrum (Table 2) of $\mathbf{1}$ exhibited 25 other signals attributed to twenty six carbons with the aid of the HETCOR and HMBC experiments. The 2,2-dimethylchromene ring linked to ring $\mathrm{A}$ at $\mathrm{C}-6$ and $\mathrm{C}-7$ and $\mathrm{C}$-prenyl group attached at $\mathrm{C}-8$ were deduced from the ${ }^{2,3} J$ correlations of the signal at $\delta_{\mathrm{H}} 5.52(d, J 9.9 \mathrm{~Hz}$ $\mathrm{H}-3 ")$ and $\delta_{\mathrm{H}} 11.42(\mathrm{OH}-5)$ with $\delta_{\mathrm{C}} 103.1(\mathrm{C}-6)$, as well as $\delta_{\mathrm{H}} 6.63(d, J 9.9 \mathrm{~Hz}, \mathrm{H}-4 ")$ and $\delta_{\mathrm{H}} 3.17(t, J 7.2 \mathrm{~Hz}$, H-1"') with the oxidized carbon at $\delta_{\mathrm{C}} 160.6$ (C-7). The location of the $\mathrm{OMe}$ and $\mathrm{OH}$ groups at C-4' and C-3' of the aromatic B-ring, respectively, was supported by the combination of the substitution pattern on the aromatic ring (1,3,4-trisubstituted) observed in the ${ }^{1} \mathrm{H}$ NMR spectrum with the ${ }^{2,3} J_{\mathrm{C}, \mathrm{H}}$ correlations from the signals at 7.02 (H-6'), 6.89 (H-5'), 7.14 (H-2') and 3.91(OMe-4') to oxidized aromatic carbon at $\delta_{\mathrm{C}} 147.1$ (C-4') and from both $\mathrm{H}-5$ ' and $\mathrm{H}-2$ ' to another oxidized aromatic carbon at $\delta_{\mathrm{C}} 145.6\left(\mathrm{C}^{-} 3^{\prime}\right)$. To confirm these positions a NOE experiment was carried out. Irradiation at $\delta_{\mathrm{H}} 6.89$ (H-5') showed nuclear over house effect with the signals at $\delta_{\mathrm{H}} 7.02$ $\left(\mathrm{H}-6^{\prime}\right)$ and $\delta_{\mathrm{H}} 3.91(\mathrm{OMe})$. All correlations are observed in Figure 2. Therefore, the structure of $\mathbf{1}$ was determined as 5,3'-dihydroxy-4'-methoxy-2", 2"'-dimethylchromene$(5 ", 6 ": 6,7)$-dihydroflavonol, which we named prenylurucuol A.

Compoud 2 was obtained as a yellow amorphous powder and its molecular formula was determined to be $\mathrm{C}_{27} \mathrm{H}_{32} \mathrm{O}_{7}$ based on its HRESITOF-MS at $\mathrm{m} / \mathrm{z} 467.2117$ $[\mathrm{M}-\mathrm{H}]^{+}$(calc. for $\mathrm{C}_{27} \mathrm{H}_{31} \mathrm{O}_{7}, 467.2069$ ). The ion peaks at

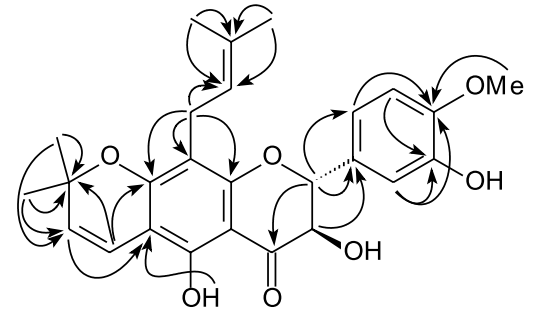

Figure 2. Key HMBC correlations of compound $\mathbf{1}$.

$\mathrm{m} / \mathrm{z}, 467$ are 14 mass units more than the corresponding peaks in 1, suggesting one additional methyl group. The presence of two $\gamma, \gamma$-dimethylallyl groups was evidenced by ${ }^{1} \mathrm{H}$ NMR signals at $\delta_{\mathrm{H}} 3.31(d, J 6.6 \mathrm{~Hz}, \mathrm{H}-1$ " $)$ and $3.22(t, J 5.7 \mathrm{~Hz}, \mathrm{H}-1$ '" '); 5.21 ( $t, J 6.6 \mathrm{~Hz}, \mathrm{H}-2$ ") and 5.12 $(t, J 6.9 \mathrm{~Hz}, \mathrm{H}-2$ "' $)$ and four singlets at $\delta_{\mathrm{H}} 1.70\left(\mathrm{H}_{3}-4 "\right)$, $1.79\left(\mathrm{H}_{3}-5 "\right), 1.66\left(\mathrm{H}_{3}-4\right.$ "') and $1.58\left(\mathrm{H}_{3}-5\right.$ "'). An OH-5 signal at $\delta_{\mathrm{H}} 11.27$ was also observed. The aromatic and C-ring proton signals of $\mathbf{2}$ (Table 1), as well as B and C-ring carbon signals (Table 2) were very similar to those of 1 . In the ${ }^{13} \mathrm{C}$ NMR spectrum two signals at $\delta_{\mathrm{C}} 55.9$ and $\delta_{\mathrm{C}} 61.6$ were observed, suggesting a diorthossubstituted OMe group. Thus, the difference between $\mathbf{1}$ and $\mathbf{2}$ is in ring A. The $\gamma, \gamma$-dimethylallyl moiety and one OMe group were confirmed as being attached at C-6 and C-7 (A-ring), respectively, based on the long-range correlations from the signal at $\delta_{\mathrm{H}} 3.31(\mathrm{H}-1 ")$ and $\delta_{\mathrm{H}} 11.27(\mathrm{OH}-5)$ with $\delta_{\mathrm{C}}$ 116.0 (C-6), and $\delta_{\mathrm{H}} 3.22$ (H-1"') and OMe-7 to C-7 ( $\delta_{\mathrm{C}}$ 165.9). From these results, the structure of 2 was identified as 5,3'-dihydroxy-7,4'-dimethoxy-6,8-dimethylallyldihydroflavonol, named prenyl-isotirumalin.

Compoud 3 was obtained as a yellow amorphous powder and its molecular formula was determined to be $\mathrm{C}_{26} \mathrm{H}_{28} \mathrm{O}_{6}$ based on its HRESITOF-MS at $\mathrm{m} / z 437.1998$ $[\mathrm{M}+\mathrm{H}]^{+}$(calc. for $\left.\mathrm{C}_{27} \mathrm{H}_{31} \mathrm{O}_{7}, 437.1964\right)$. The ${ }^{1} \mathrm{H}$ and ${ }^{13} \mathrm{C}$ NMR data (Tables 1 and 2) of compound 3 were very similar to those reported for $\mathbf{1}$, indicating the presence of 1,3,4-trisubstituted and pentasubstituted aromatic rings, as 
well as a 2,2-dimethylchromene ring. The main differences between the spectroscopic data of compound $\mathbf{3}$ are signals for three double duplets at $\delta_{\mathrm{H}} 5.31(d d, J 3.0$ and $12.9 \mathrm{~Hz}$, $\mathrm{H}-2), \delta_{\mathrm{H}} 2.81(d d, J 3.0$ and $17.1 \mathrm{~Hz}, \mathrm{H}-3 \beta)$ and $\delta_{\mathrm{H}} 3.05(d d$, $J 17.1$ and $12.9 \mathrm{~Hz}, \mathrm{H}-3 \alpha$ ), which showed correlations with the signals at $\delta_{\mathrm{C}} 78.5(\mathrm{C}-2)$ and $43.3(\mathrm{C}-3)$, respectively, in the HETCOR spectrum, suggesting it to be a flavanone. The substitution pattern of B-ring showed the same AMX system as that of compounds $\mathbf{1}$ and $\mathbf{2}$. The presence of $\mathrm{OH}$ at C-3' and $\mathrm{OMe}$ at C-4' was supported by means ${ }^{3} J$ correlation at $\delta_{\mathrm{H}} 5.71$ signal, attributed to $\mathrm{OH}$ phenolic, with $\delta_{\mathrm{C}} 112.5$ $\left(\mathrm{C}^{2}{ }^{\prime}\right)$ and $\delta_{\mathrm{C}} 145.7$ (C-3') as well as by irradiation at $\delta_{\mathrm{H}} 3.92$ that showed NOE with the signal at $\delta_{\mathrm{H}} 6.87(d$, $J 8.4 \mathrm{~Hz}, \mathrm{H}-5$ '). The presence of OH-5 was confirmed by the signal at $\delta_{\mathrm{H}}$ 12.25. Thus, compound 3 is 5,3'-dihydroxy4'-methoxy-8-allyl-2",2"'- dimethylchromene -(6,7:5",6") flavanone, named 3'-methoxylupinifolin.

Compoud 4 was obtained as a yellow amorphous powder and its molecular formula was determined to be $\mathrm{C}_{27} \mathrm{H}_{32} \mathrm{O}_{6}$ based on its HRESITOF-MS at $\mathrm{m} / z$, 453.2270 $[\mathrm{M}+\mathrm{H}]^{+}$(calc. for $\mathrm{C}_{27} \mathrm{H}_{33} \mathrm{O}_{6}, 453.2277$ ). The ${ }^{1} \mathrm{H}$ and ${ }^{13} \mathrm{C}$ NMR data (Tables 1 and 2 ) of compound 4 were very similar to those reported for $\mathbf{2}$ and $\mathbf{3}$. The ${ }^{1} \mathrm{H}$ NMR spectrum showed signals for three double duplets at $\delta_{\mathrm{H}} 5.30(d d, J 3.0$ and $12.9 \mathrm{~Hz}, \mathrm{H}-2), \delta_{\mathrm{H}} 2.82(d d, J 3.0$ and $17.1 \mathrm{~Hz}, \mathrm{H}-3 \beta)$ and $\delta_{\mathrm{H}} 3.06(d d, J 17.1$ and $12.9 \mathrm{~Hz}, \mathrm{H}-3 \alpha)$, which showed correlations with the signals at $\delta_{\mathrm{C}} 78.4(\mathrm{C}-2)$ and $43.5(\mathrm{C}-3)$, respectively, in the HETCOR spectrum, thus compound 4 is a flavanone. The substitution pattern of B-ring showed the same AMX system as that of $\mathbf{1 , 2}$ and $\mathbf{3}$ for $\mathrm{B}$ aromatic ring. The presence of $\mathrm{OH}-5$ was confirmed by the signal at $\delta_{\mathrm{H}}$ 12.05. The presence of two $\gamma, \gamma$-dimethylallyl groups was evidenced by signals at $\delta_{\mathrm{H}} 3.29(d, J 6.6 \mathrm{~Hz}, \mathrm{H}-1$ ") and 3.25 $(d, J 6.7 \mathrm{~Hz}, \mathrm{H}-1$ '") $) 5.21$ ( $t t, J 0.9$ and $7.8 \mathrm{~Hz}, \mathrm{H}-2$ ") ) and $5.15\left(t t, J 1.5\right.$ and $7.8 \mathrm{~Hz}, \mathrm{H}-2$ '”') and four singlets at $\delta_{\mathrm{H}} 1.68$ $\left(\mathrm{H}_{3}-4 "\right), 1.77\left(\mathrm{H}_{3}-5 "\right), 1.66\left(\mathrm{H}_{3}-4\right.$ "') and $1.63\left(\mathrm{H}_{3}-5\right.$ "'). The signal observed at $\delta_{\mathrm{H}} 3.75\left(\delta_{\mathrm{C}} 61.6\right)$ suggest the presence of a diorthosubstituited OMe group as observed for $\mathbf{2}$. Thus the compound 4 is 5,3'-dihydroxy-7,4'-dimethoxy-6,8dimethylallyl-flavanone named prenylutiline.

Compoud 5 was obtained as a yellow amorphous powder and its molecular formula was determined to be $\mathrm{C}_{27} \mathrm{H}_{30} \mathrm{O}_{7}$ based on its HRESITOF-MS at $\mathrm{m} / z$ 467.2064 $[\mathrm{M}+\mathrm{H}]+$ (calc. for $\left.\mathrm{C}_{27} \mathrm{H}_{31} \mathrm{O}_{7}, 467.2069\right)$. The presence of

Table 1. ${ }^{1} \mathrm{H}$ NMR chemical shifts $\left(\delta_{\mathrm{H}}\right.$ in ppm) and coupling constant $(\mathrm{J}$ in $\mathrm{Hz})$ of compounds $\mathbf{1 - 5}$ in $\mathrm{CDCl}_{3}$

\begin{tabular}{|c|c|c|c|c|c|}
\hline $\mathrm{H}$ & 1 & 2 & 3 & 4 & 5 \\
\hline 2 & $4.95(\mathrm{~d}, 11.7)$ & $4.96(\mathrm{~d}, 12.0)$ & $5.31(\mathrm{dd}, 12.9$ and 3.0$)$ & $5.30(\mathrm{dd}, 12.9$ and 3.0$)$ & - \\
\hline 3 & $4.47(\mathrm{~d}, 11.7)$ & $4.50(\mathrm{~d}, 12.0)$ & $\begin{array}{c}\beta 2.81(\mathrm{dd}, 17.1 \text { and } 3.0) \\
\alpha 3.05(\mathrm{dd}, 17.1 \text { and } 12.9)\end{array}$ & $\begin{array}{l}\beta 2.82(\mathrm{dd}, 17.1 \text { and } 3.0) \\
\alpha 3.06(\mathrm{dd}, 17.1 \text { and } 12.9)\end{array}$ & - \\
\hline $2^{\prime}$ & $7.14(\mathrm{~d}, 1.6)$ & $7.14(\mathrm{~d}, 2.1)$ & $7.04(\mathrm{~d}, 1.8)$ & $7.03(\mathrm{~d}, 1.8)$ & $7.77(\mathrm{~d}, 1.8)$ \\
\hline 5 & $6.89(\mathrm{~d}, 8.1)$ & $6.90(\mathrm{~d}, 8.4)$ & $6.87(\mathrm{~d}, 8.4)$ & $6.87(\mathrm{~d}, 8.2)$ & $6.97(\mathrm{~d}, 8.4)$ \\
\hline 6' & $7.02(\mathrm{dd}, 8.1$ and 1.6$)$ & $7.00(\mathrm{dd}, 8.4$ and 2.1$)$ & $6.92(\mathrm{dd}, 8.4$ and 1.8$)$ & $6.91(\mathrm{dd}, 8.2$ and 1.8$)$ & $7.82(\mathrm{dd}, 8.4$ and 1.8$)$ \\
\hline $1 "$ & - & $3.31(\mathrm{~d}, 6.6)$ & - & $3.29(\mathrm{~d}, 6.6)$ & $3.41(\mathrm{~d}, 6.0)$ \\
\hline $2 "$ & - & $5.21(\mathrm{t}, 6.6)$ & - & $5.21(\mathrm{tt}, 7.8$ and 0.9$)$ & $5.24(\mathrm{br} \mathrm{d}, 7.8)$ \\
\hline 3" & $5.52(\mathrm{~d}, 9.9)$ & - & $5.49(\mathrm{~d}, 9.9)$ & - & \\
\hline 4" & $6.63(\mathrm{~d}, 9.9)$ & $1.70(\mathrm{~s})$ & $6.63(\mathrm{~d}, 9.9)$ & $1.68(\mathrm{~s})$ & $1.81(\mathrm{~s})$ \\
\hline $5 "$ & $1.44(\mathrm{~s})$ & $1.79(\mathrm{~s})$ & $1.44(\mathrm{~s})$ & $1.77(\mathrm{~s})$ & $1.70(\mathrm{~s})$ \\
\hline $6 "$ & $1.44(\mathrm{~s})$ & - & $1.43(\mathrm{~s})$ & - & - \\
\hline $1 " ”$ & $3.17(\mathrm{t}, 7.2)$ & $3.22(\mathrm{t}, 5.7)$ & $3.21(\mathrm{~d}, 7.2)$ & $3.25(\mathrm{~d}, 6.7)$ & $3.58(\mathrm{~d}, 6.0)$ \\
\hline $2 " ”$ & $5.12(\mathrm{bt})$ & $5.12(\mathrm{t}, 6.9)$ & $5.15(\mathrm{t}, 6.7)$ & $5.15(\mathrm{tt}, 7.8$ and 1.5$)$ & $5.24($ br d, 7.8$)$ \\
\hline $3 ”$, & - & - & - & - & - \\
\hline $4 "$, & $1.65(\mathrm{~s})$ & $1.66(\mathrm{~s})$ & $1.66(\mathrm{~s})$ & $1.66(\mathrm{~s})$ & $1.86(\mathrm{~s})$ \\
\hline $5 " ”$ & $1.62(\mathrm{~s})$ & $1.58(\mathrm{~s})$ & $1.66(\mathrm{~s})$ & $1.63(\mathrm{~s})$ & $1.72(\mathrm{~s})$ \\
\hline OMe-4' & $3.91(\mathrm{~s})$ & $3.92(\mathrm{~s})$ & $3.92(\mathrm{~s})$ & $3.92(\mathrm{~s})$ & $3.98(\mathrm{~s})$ \\
\hline OMe-7 & - & $3.77(\mathrm{~s})$ & - & $3.75(\mathrm{~s})$ & $3.80(\mathrm{~s})$ \\
\hline $\mathrm{OH}-5$ & $11.42(\mathrm{~s})$ & $11.27(\mathrm{~s})$ & $12.25(\mathrm{~s})$ & $12.05(\mathrm{~s})$ & $11.86(\mathrm{~s})$ \\
\hline $\mathrm{OH}$ & $5.80(\mathrm{br} \mathrm{s})$ & 5.75 (br s) & $5.71(\mathrm{br} \mathrm{s})$ & - & - \\
\hline
\end{tabular}

${ }^{1} \mathrm{H}$ NMR data were recorded at $300 \mathrm{MHz}$. Multiplicity and coupling constant $(\mathrm{J}, \mathrm{Hz})$ are in parenthesis. 
two $\gamma, \gamma$-dimethylallyl groups was evidenced by ${ }^{1} \mathrm{H}$ NMR signals (Table 1) at $\delta_{\mathrm{H}} 3.41(d, J 6.0 \mathrm{~Hz}, \mathrm{H}-1$ ") and 3.58 $(d, J 6.0 \mathrm{~Hz}, \mathrm{H}-1$ "' $) ; 5.24$ ( $b r d, J 7.8 \mathrm{~Hz}, \mathrm{H}-2$ ") $)$, as well as four singlets at $\delta_{\mathrm{H}} 1.81\left(\mathrm{H}_{3}-4\right.$ "), $1.70\left(\mathrm{H}_{3}-5\right.$ "), $1.86\left(\mathrm{H}_{3}-4\right.$ "”) and $1.72\left(\mathrm{H}_{3}-5\right.$ "'). In the ${ }^{1} \mathrm{H}$ NMR spectrum a characteristic proton signal of OH-5 at $\delta_{\mathrm{H}} 11.86$ was observed as well as two singlets at $\delta_{\mathrm{H}} 3.98(56.0)$ and $3.80(62.0)$ suggesting a diorthossubstituted OMe group as observed for compounds 2 and 4. The same AMX patterned substation of the B-ring of compounds 1-4 was observed. Based on the ion peak at $m / z 467$ and the presence of the 27 signals in the ${ }^{13} \mathrm{C}$ NMR spectrum, compound $\mathbf{5}$ is a flavonol. An OMe was establish at C-4 by means of correlations between $\delta_{\mathrm{H}} 6.97(d, J 8.4 \mathrm{~Hz}, \mathrm{H}-5$ ') 7.82 ( $d d, J 1.8$ and $8.4 \mathrm{~Hz}$, H-6') and $3.98(\mathrm{OMe})$ with $\delta_{\mathrm{C}} 148.2$. Thus compound 5 is 3,5,3'-trihydroxy-7,4'-dimethoxy-6,8-dimethylallylflavanol named prenylutilinol.

Table 2. ${ }^{13} \mathrm{C}$ NMR chemical shifts $\left(\delta_{\mathrm{C}}\right.$ in ppm) of compounds $\mathbf{1 - 5}$ in $\mathrm{CDCl}_{3}$

\begin{tabular}{|c|c|c|c|c|c|}
\hline \multirow{2}{*}{$\mathrm{C}$} & \multicolumn{5}{|c|}{$\delta_{\mathrm{C}}$} \\
\hline & 1 & 2 & 3 & 4 & 5 \\
\hline 2 & 82.8 & 82.8 & 78.5 & 78.4 & 145.6 \\
\hline 3 & 72.4 & 72.8 & 43.3 & 43.5 & 136.0 \\
\hline 4 & 196.2 & 197.5 & 196.4 & 197.5 & 175.8 \\
\hline 5 & 155.8 & 158.9 & 156.3 & 159.5 & 156.1 \\
\hline 6 & 103.1 & 116.0 & 102.8 & 115.5 & 117.3 \\
\hline 7 & 160.6 & 165.9 & 160.0 & 165.0 & 162.5 \\
\hline 8 & 109.2 & 114.6 & 108.6 & 114.0 & 113.6 \\
\hline 9 & 159.2 & 158.2 & 159.3 & 158.2 & 152.4 \\
\hline 10 & 100.2 & 103.0 & 102.6 & 105.3 & 106.1 \\
\hline 1 ' & 129.6 & 129.6 & 132.0 & 132.0 & 124.3 \\
\hline $2^{\prime}$ & 113.5 & 113.4 & 112.5 & 112.5 & 113.7 \\
\hline $3^{\prime}$ & 145.6 & 145.6 & 145.7 & 1457 & 145.7 \\
\hline $4^{\prime}$ & 147.1 & 147.0 & 147.0 & 146.7 & 148.2 \\
\hline 5 & 110.3 & 110.3 & 110.5 & 110.5 & 110.4 \\
\hline $6^{\prime}$ & 119.5 & 119.5 & 117.8 & 117.8 & 121.0 \\
\hline $1 "$ & - & 22.5 & - & 22.2 & 22.5 \\
\hline $2 "$ & 78.4 & 122.5 & 78.0 & 122.8 & 122.4 \\
\hline $3 "$ & 126.2 & 131.9 & 126.0 & 131.6 & 132.0 \\
\hline $4 "$ & 115.4 & 25.7 & 115.6 & 25.7 & 17.9 \\
\hline $5 "$ & 28.3 & 17.8 & 28.3 & 17.9 & 25.6 \\
\hline $6 "$ & 28.3 & - & 28.3 & & - \\
\hline $1 "$, & 21.2 & 22.2 & 21.4 & 22.7 & 22.8 \\
\hline $2 "$, & 122.1 & 122.5 & 122.5 & 123.0 & 122.8 \\
\hline 3"' & 131.3 & 131.6 & 131.0 & 131.4 & 132.4 \\
\hline $4 "$, & 25.7 & 25.7 & 25.8 & 25.7 & 18.1 \\
\hline $5 "$, & 17.7 & 17.7 & 17.8 & 17.8 & 25.7 \\
\hline OMe-7 & - & 61.6 & - & 61.6 & 62.0 \\
\hline OMe-4' & 55.9 & 55.9 & 56.0 & 56.0 & 56.0 \\
\hline
\end{tabular}

\section{Neuroprotective properties}

Immunocytochemical analysis indicated that our culture procedures resulted in a mixed pattern of neurons and glia (Figure 3) with the following composition: $10.38 \%$ $( \pm 3.75)$ of the neurons were catecholaminergic (positive for anti-tirosine hidroxylase antibody), $14.57 \%( \pm 2.74)$ were astrocytes (positive for anti-GFAP antibody) and 9.58\% $( \pm 1.97)$ were microglia (positive for OX-42 antibody), out of the total cell number revealed by counterstaining with Nissl.

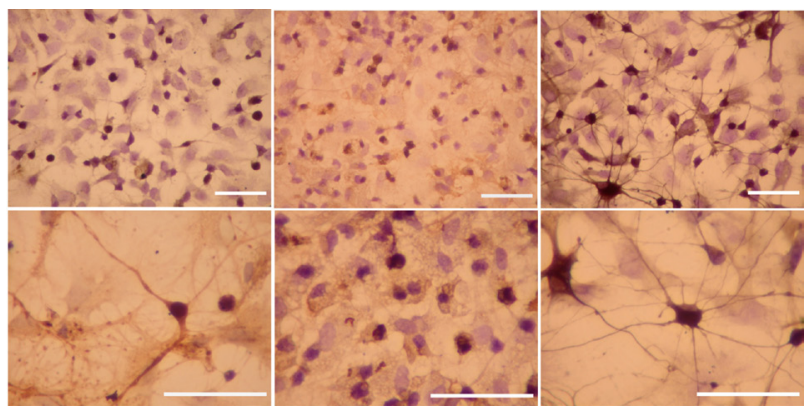

Figure 3. Immunocytochemical caracterization of hippocampal primary cultures as a mixture of neurons and glial cells. Catecholaminergic neurons (TH-positive cells) are shown in the left column, microglia (OX-42 positive-cells) in the middle and astrocytes (GFAP-positive cells) in the right column. Bar $=50 \mu \mathrm{m}$.

In the cultures, exposure to $30 \mathrm{nmol} \mathrm{L}^{-1}$ rotenone for $72 \mathrm{~h}$ resulted in significant reduction (19.4\%) in cell viability when compared to control cultures (Figure 4). Exposure to DMSO in the same concentration used to dilute rotenone had no statistically significant effect on cell viability. Likewise, the addition of increasing concentrations (3, 5 and $10 \mu \mathrm{g} \mathrm{mL}^{-1}$ ) of the FR3 fraction tested in this study had no significant effect on the viability of the hippocampal cells. On the other hand, concomitant exposure of the cultures to $30 \mathrm{nmol} \mathrm{L}^{-1}$ rotenone and FR3 fraction of Deguelia leaves

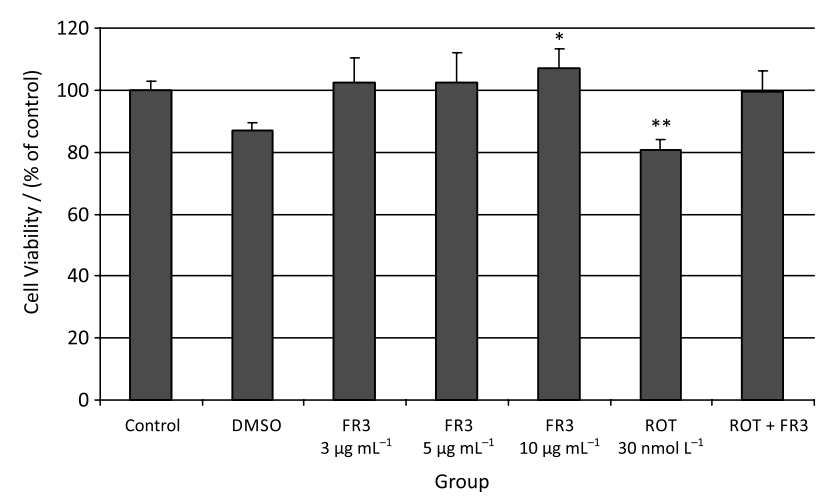

Figure 4. Effect of FR3 on the cell viability of primary hippocampal cells in rotenone-treated cultures. $100 \%$ corresponds to the total number of cells after 7 DIV in untreated controls. Values represent the means \pm SEM of three independent experiments with two wells in each treatment. * $\mathrm{p}<0.05$ compared to control group. ${ }^{* *} \mathrm{p}<0.05$ compared to rotenone group. 
$\left(5 \mu \mathrm{g} \mathrm{mL}{ }^{-1}\right)$ for $72 \mathrm{~h}$ resulted in increased cell viability (to 99.6\%), when compared with cell cultures treated with rotenone alone (negative control). These results suggest that FR3 provided significant protection to hippocampal cells against rotenone-induced toxicity.

Importantly, the FR3 fraction is a flavonoid mixture that contains substances 1 to $\mathbf{7}$. Several studies attribute significant neuroprotective effects to flavonoid compounds, and this has been frequently associated with the antioxidant properties of these substances, ${ }^{22-24}$ which could explain the observed cytoprotection effects of FR3 in our animal model of neurodegeneration. Thus, we propose that such an effect is related to the high contents of flavonoids present in the leaves. Noteworthy is the fact that the same species provides high concentration of rotenone, a known neurotoxic compound, ${ }^{25}$ together with neuroprotective substances present in its leaves.

\section{Conclusions}

The present phytochemical study of the leaves of Deguelia utilis afforded five new flavonoids, named as prenyl-urucuol A (1), prenyl-isotirumalin (2), 3'-methoxylupinifolin (3), prenylutiline (4) and prenylutilinol (5). A fraction containing all these flavonoids (FR3) showed significant cell viability when compared with cell cultures treated with rotenone, a mitochondrial complex I inhibitor, strongly suggesting a cytoprotective effect for this fraction.

\section{Supplementary Information}

${ }^{1} \mathrm{H}$ NMR, ${ }^{13} \mathrm{C}$ NMR spectra, HMBC correlations for compounds 1-5 are available free of charge at http://jbcs.sbq.org.br as PDF file.

\section{Acknowledgments}

The authors are grateful to the Conselho Nacional de Desenvolvimento Científico e Tecnológico (CNPq) and to the Fundação de Amparo à Pesquisa do Estado do Pará (FAPESPA) for financial support and scholarships. We are also thankful to Dr. Norberto P. Lopes from the Faculdade de Ciências Farmacêuticas de Ribeirão Preto, USP for the HRESITOF-MS.

\section{References}

1. Migliore, L. L.; Coppedè, F.; Mutat. Res. 2009, 674, 73.

2. Newman, D. J.; Cragg, G. M.; Snader, K. M.; J. Nat. Prod. 2003, 66, 1022.
3. Harbone, J. B.; Mabry, T. J.; Mabry, H.; The Flavonoids, $2^{\text {nd }}$ ed.: Chapman \& Hall: London, 1975, p. 376.

4. Lin, Y. L.; Chen, Y. L.; Kuo, Y. H.; J. Nat. Prod. 1993, 56, 1187.

5. Filho, R. B.; Gottlieb, O. R.; Mourão, A. P.; Phytochemistry 1975, 14, 261.

6. Horowitz, M. P.; Greenamyre, J. T.; Clin. Pharmacol. Ther. 2010, 88, 467.

7. Kaquadji, M.; Agban, A.; Mariotte, A. M.; J. Nat. Prod. 1986, 49, 281

8. Garcia, M.; Kano, M. H. C.; Vieira, D. M.; do Nascimento, M. C.; Mors, W. B.; Phytochemistry 1986, 25, 2425.

9. Fang, N.; Casida, J. E.; J. Agric. Food Chem. 1999, 47, 2130.

10. Magalhães, A. F.; Tozzi, A. M. G. A.; Magalhães, E. G.; Moraes, V. R. S.; Phytochemistry 2001, 57, 77.

11. Lawson, M. A.; Kaquadji, M.; Allais, D. P.; Tetrahedron Lett. 2006, $47,451$.

12. Lawson, M. A.; Kaquadji, M.; Chulia, A. J.; Tetrahedron Lett. 2008, 49, 2407.

13. Lôbo, L. T.; da Silva, G. A.; Ferreira, M.; da Silva, M. N.; Santos, A. S.; Arruda, A. C.; Guilhon, G. M. S. P.; Santos, L. S.; Borges, R. S.; Arruda, M. S. P.; J. Braz. Chem. Soc. 2009, 20, 1082.

14. Lôbo, L. T.; da Silva, G. A.; Freitas, M. C. C.; Souza Filho, A. P. S.; da Silva, M. N.; Arruda, A. C.; Guilhon, G. M. S. P.; Santos, L. S.; Santos, A. S.; Arruda, M. S. P.; J. Braz. Chem. Soc. 2010, 21, 1838.

15. Costa, E. T.; Oliveira, D. S.; Meyer, D. A.; Ferreira, V. M. M.; Soto, E. E.; Frausto, S.; Savage, D. D.; Browning, M. D.; Valenzuela, C. F.; J. Biol. Chem. 2000, 275, 38268.

16. Gao, H. M.; Hong, J. S.; Zhang, W.; Liu, B.; J. Neurosci. 2002 , 22,782 .

17. Grammatopoulos, T. N.; Ahmadi, F.; Jones, S. M.; Fariss, M. W.; Weyhenmeyer, J. A.; Zawada, W. M.; Brain Res. 2005, 1045, 64 .

18. Testa, C.M.; Sherera, T. B.; Greenamyre, J. T.; Mol. Brain. Res. 2005, 134, 109.

19. Tiwari, M.; Lopez-Cruzan, M.; Morgan, W. W.; Herman, B.; J. Biol. Chem. 2011, 286, 8493.

20. Fang, N.; Casida, J. E.; J. Nat. Prod. 1999, 62, 205.

21. Kaouadji, M.; Agban, A.; Mariotte, A. M.; Tissut, M.; J. Nat. Prod. 1986, 49, 281.

22. Seaton, T. A.; Cooper, J. M.; Schapira, A. H.; Brain Res. 1997, $777,110$.

23. Moldzio, R., Radad. K., Krewenka, C.; Kranner, B.; Duvigneau, J. C.; Wang, Y.; Rausch, W. D.; J. Neural Transm. 2010, 117, 5.

24. Radad, K.; Moldzio, R.; Taha, M.; Rausch, W. D.; Phytother. Res. 2009, 23, 696.

25. Da Costa, J. P. C.; Alves, S. M.; Belo, M.; Acta Amaz. 1999, $29,563$.

Submitted: January 28, 2012 Published online: November 1, 2012 